Vol. 3, No. 01; 2020

ISSN: 2581-4664

\title{
THE EFFECT OF SPECIAL PRICE, SHOPPING PLEASURE AND WILLINGNESS TO PAY ON HEDONIC PURCHASE AND IMPULSIVE BUYING IN SUZUYA DEPARTMENT OF STORE BANDA ACEH, INDONESIA
}

\author{
Liza Andalia, MirzaTabrani and Nurdasila Darsono \\ Department of Management, Universitas Syiah Kuala, Indoneisa \\ http://doi.org/10.35409/IJBMER.2020.3137
}

\begin{abstract}
The study is to determine the effect of special price, shopping pleasure and willingness to pay on hedonic purchase and impulsive buying in suzuya department of store banda aceh, Indonesia. The population in this study is infinite so sampling is a non probability sampling. In this study, it takes 150 people as a sample. The data is tested and analyzed using Structural Equation Model (SEM) as a statistical method, with AMOS software as a tool. The result shows that special price effects impulsive buying; shopping pleasure effects impulsive buying; willingness to pay effects impulsive buying; special price effects on hedonic purchase; shopping pleasure effects hedonic purchase, and; willingness to pay effects the hedonic purchase. These all findings also have an implication to academic area. There will be as a reference for further research to be developed, as this research proves the causality theories and this is being a new premise/ update theories. The originality lies in the integration of the causality test from the previous researches, and also the use of SEM as a statistical approach. The limitation is in the number of variables that are only four, and with one object.
\end{abstract}

Keyword: Special Price, Shopping Pleasure, Willingness to Pay, Hedonic Purchases and Impulsive Buying.

\section{INTRODUCTION}

Impulsive buying at the Suzuya Department Store Banda Aceh is one factor that is not planned by consumers in buying products, such as clothing products, accessories and food products offered by the company. What strategies are used by the Suzuya Department Store in Banda Aceh is to increase sales volume and company targets. This effort is carried out to attract certain consumer segments, namely the middle and upper economic community and groups of young mothers, and help them appear in increasingly competitive markets. Companies should not assume that increasing the market share they serve must increase their profitability.

The result of research conducted by (Syahputra, Yunus, \& Ibrahim, 2017) proved that hedonism has a significant influence on online product unplanned purchasing decisions for the people of Banda Aceh City.

Purchasing at the Suzuya Department Store in Banda Aceh can help improve the 


\section{International Journal of Business Management and Economic Review}

Vol. 3, No. 01; 2020

ISSN: 2581-4664

consumer's image and position the products purchased in his mind. To increase unplanned purchases at the Banda Aceh Suzuya Department Store, it is necessary to know the factors that can influence someone to make an unplanned purchase, namely: the urgency to buy, namely the existence of certain interests or the urgent need to make purchases due to products that have never been seen or felt before, then the positive thinking factor that the product that will be purchased will provide benefits to consumers even if purchased unplanned. Negative affect is one of the factors that also influence consumers to make unplanned purchases, because negative influences that come from outside themselves such as the influence of friends or other family members who tell to buy while consumers themselves do not want the product.

A person's decision as a buyer or product is greatly influenced by the presence of personal characteristics, namely the age of the buyer and life cycle, work, lifestyle, economic condition, economic condition, and personality, personality concept and the buyer itself. In addition, environmental factors related to purchasing decisions.

There are 2 factors that can influence purchase intentions and purchasing decisions. The first factor is the attitude or establishment of other people such as close friends, the intention of the purchase is also influenced by factors that are not anticipated. Consumers form a purchase intention on the basis of factors such as expected family income, expected prices and expected product benefits. When consumers will act factors that are not anticipated situations may occur to change the intent and purchase (Kotler \& Keller, 2018).

Banda Aceh is a city with population growth and a relatively high income level compared to other cities in Aceh, this can be seen from the lifestyle of the people of Banda Aceh who tend to be hedonic lifestyle, compared to other communities in other cities in Aceh, p. This can be seen from the many products purchased by the people of Banda Aceh such as twowheeled vehicles, new cars that filled the streets of Banda Aceh, ongoing construction of shops, the establishment of modern shopping centers such as Hemes Mall and Suzuya Mall and many supermarkets in The city of Banda Aceh, which signifies the level of income of the people of Banda Aceh City is high, this certainly will also affect the lifestyle of the people of Banda Aceh to live hedonically.

Suzuya Department Store Banda Aceh is one of the modern shopping centers with a variety of modern shopping facilities, which creates a comfortable, flexible shopping environment that leads to a consumer behavior approach. Suzuya Department Store Banda Aceh. Its location is very strategic allowing people to reach it easily, both those using private vehicles and public transportation.

Then the research conducted by (Ginting \& Nasri, 2018)proved that the amount of expenditure and health costs affect students' Willingness To Pay (WTP). the price of cigarettes and the effects of writing do not affect student PAPs. the value of WTP paid by the respondent is Rp. 17.650. the number of respondents who are willing to pay and not willing, it can be seen that from 100 respondents.

In addition in attracting consumers who want to shop without planning (impulsive buying), the Suzuya Department Store Banda Aceh also provides special prices for customers, so it can attract consumers to buy these products, such as product discounts, discounts when buying products. certain products are for the same brand and there are different price variations compared to other stores or outlets in Banda Aceh City.

Suzuya Department Store Banda Aceh provides complete consumer needs ranging from 


\section{International Journal of Business Management and Economic Review}

Vol. 3, No. 01; 2020

ISSN: 2581-4664

food products and not food and various kinds of services. Suzuya Department Store Banda Aceh features two main shops, Suzuya Mall, where Suzuya Mall has outlets such as Mister Baso, Ace Hardware, Sundanese Chef and KFC outlets and others. With a large, clean, comfortable place and many shopping options that make Suzuya Department Store Banda Aceh.

A hedonic attitude is a life view that assumes that people will be happy by seeking happiness as much as possible and avoiding painful feelings wherever possible. Hedonism is a teaching or view that pleasure or pleasure is the purpose of life and human action.

Research by (Fazila, 2018) states that consumers' unplanned purchase decisions at Medan Fair Plaza Medan City are influenced by the factors of the pleasure of shopping and the availability of money.

Based on the phenomenon that occurred in Banda Aceh that the hedonic attitude of the people of Banda Aceh in shopping and making unplanned purchases was influenced by several factors such as the special prices offered by the Suzuya Department Store in Banda Aceh in the form of discounts for some products such as food products and products clothes that often get special prices. Then the pleasure factor of shopping from consumers, this causes a hedonic attitude from consumers so that they make unplanned purchases. Shopping pleasure shown by consumers is due to the availability of money, so consumers can buy products that have never been purchased or products that have never been felt by consumers so that they make unplanned purchase decisions.

\section{LITERATURE REVIEW}

\section{Impulsive Buying}

Impulsive purchases are widespread in Americanmarketplace today, and have been a target market and consumer research for more than forty years (for example, (Applebaum, 1951); (Bellenger, Robertson, \& Hirschman, 1978); (Clover, 1950); (Cobb \& Hoyer, 1986); (Co, n.d.); (Katona \& Mueller, n.d.) ; (Kollat \& Willett, 1969); (Rook, 1987). Contempory marketing innovations such as 24-hour retailing, telemarketing, cash machines, "instant credit" and home shopping networks make it easier for consumers to operate at the present desire than before. Apart from the importance of impulse buying at Americatoday, we know very little about the dynamics of this type of buyer behavior. One way to gain insight into the motivation of impulsive buying is to investigate the feelings that follow it. From this perspective, moodstate can be interpreted as an element oriented to the influence of impulse buying events. For example, (Weinberg \& Gottwald, 1982), (Rook \& Hoch, 1985), and (Rook, 1987) reported that impulse purchases were more intense and tempting than contemplative purchases.

Impulsive buying is an important aspect of consumer behavior that contains interesting points to understand marketing efforts. In the marketing literature, impulsive purchases are defined as experiencing sudden, strong, and tempting spending tendencies (Arnold \& Reynolds, 2003). Impulsive purchases occur when someone immediately purchases a product that is not planned and without thinking. This form of purchase is not intentional because the individual is not looking for a particular product and does not have the slightest intention to buy. Being unintentional and unplanned are two important components of impulse buying but not the only criteria for purchases that will be placed in this category (Dawson \& Kim, 2009). People involved in impulse purchases tend not to consider the consequences of this buying action. This 


\section{International Journal of Business Management and Economic Review}

Vol. 3, No. 01; 2020

ISSN: 2581-4664

individual focuses on direct satisfaction in fulfilling the tendency to buy and not thinking about solving problems that have previously been made (Burgess, Dickson, \& Macmillan, 2014). After a direct sense of buying a product without considering the logic of buying a product, impulse buying behavior occurs. This kind of coercion is sometimes not manageable, and causes buyers to temporarily ignore the results of this type of expenditure (Vohs \& Faber, 2007).

Impulsive purchases can be explained as choices made at that time because of strong positive feelings about an object. Impulsive purchases can also be explained as "lackluster reactive behavior". This purchase involves a strong affective state in which consumers behave rather automatically, by carrying out a little intellectual control over consumer actions.

According to (Mowen \& Minor, 2002), states that impulse purchase is an act of buying that is done without having a previous problem or intention (purchase intention) formed before entering the store.

Impulsive buying is the antithesis of a rational consumption process that characterizes most high-involvement purchases and even some low-involvement purchases. The influence of mood influences whether consumers will use a decision-making approach or experience to make choices. Communities in positive moods respond more favorably to emotional appeal and to the attractiveness of information and, on the other hand, people in negative moods respond more favorably to information attractiveness.

According to (Setiadi, 2013), impulsive purchases have a reasonable basis for consideration. Self service and open display systems have created a marketing situation where planning can be delayed until the buyer enters the store.

\section{Hedonic Purchase}

Hedonic consumer consumption behavior plays an important role in consumption activities. This level of behavior varies according to consumer characteristics. In this context, it can be stated that hedonic expenditure differentiates based on sex, that men show more rational buying behavior, and that women shop in hopes of pleasure (Ozdemir, 2007); (Jackson, Currie, Graham, \& Robb, 2011); (Çakmak \& Çakır, 2012) . Furthermore, hedonic consumption habits have a positive effect on the desire to buy (Činjarević, Tatic, \& Petric, 2011). According to (Erkmen \& Yuksel, 2008), consumers who act more with hedonic instincts are people who spend more time shopping for their free time, such as looking around, buying things for sure while shopping and using credit card installments. Such behavior is also influenced by the design of shopping centers (Budisantoso \& Mizerski, 2011) and visual and audial aspects. (Langrehr, 1991) has emphasized that shopping centers affect consumers who exhibit hedonic buying behavior and that businesses must be aware of it. According to him, the level of color use affects individuals both in imaginary and hedonic terms; while warm colors like red and yellow stimulate action, and cold colors like blue and green cause individuals to think and wait longer. In addition, music in stores, sound in it, noise and temperature levels are other aspects that influence consumer behavior.

Hedonic consumption is an important concept not only for conventional stores, but also for non-conventional stores. The findings of the study of online shopping by (Mai, Menon, \& Sarkar, 2006), in this context, are very striking. According to this, consumers with hedonic consumption habits prefer to interact with products. 


\section{International Journal of Business Management and Economic Review}

Vol. 3, No. 01; 2020

ISSN: 2581-4664

\section{Special Price}

In the current marketing environment, price and product quality are the main problems, but not only in the consumer decision-making process and the result of their overall satisfaction but the decision making and marketing strategies of the producer. The concept of quality takes special emphasis when there is juxtapose to the price that consumers can afford. According to (Dolan \& Simon, 1996), prices are the biggest marketing head for managers, and that's where they feel the greatest pressure to do and most uncertain that they do a good job. Price decisions must consider the reaction of customers and competitors. In formal use, customers will generally regard prices as an indicator of product or service quality and will usually evaluate costs in terms of perceived benefits derived from consumption of offers. In most cases, customers have the opportunity to choose from a variety of offers and thus prices will be one of the comparative indicators where their purchasing decisions will be based (Kenny \& Dyson, 2018). The main determinant of price, of course, is what consumers are ready to pay, which in turn is related to a number of other factors including quality. Price is one element of the marketing mix. This can change very easily compared to other elements of the marketing mix. Marketers can decide to reduce or increase prices more often.

\section{Shopping Pleasure}

In line with the stimulus-organism-response (SOR) model, which states that the environment $(\mathrm{S})$ influences the affective and cognitive experiences of individuals $(\mathrm{O})$ which immediately approaches / avoids responses ( $\mathrm{R}$, for example, the desire to) towards the environment(Mary Jo Bitner, 1992); (Donovan, Rossiter, Marcoolyn, \& Nesdale, 1994); (Mehrabian \& Russell, 1974), IITs from Aretail Web sites can influence cognition and influence which have an impact on approach responses. In particular, the use of IIT features on websites can signify a change from myopic focus on rational consumers driven by the need to include people who are looking for aspects of hedonic experience, which consists of sensory pleasure, satisfying emotional experience, mental play, and fantasy accordingly (Hirschman \& Holbrook, 1982). Mental games and feelings can produce emotional experiences (affective) (Fiore and $\mathrm{Yu}$, 2001); in this case afectiveexperience is generated during mental play when coordinating product images using the IIT feature. Affective experiences involved in the consumption process can be represented by two dimensions, passion and pleasure (Donovan et al., 1994); (Holbrook, 1986); (Mehrabian \& Russell, 1974). Passion refers to the dreeties that are stimulated, excited, or alert in this situation, while pleasure is an evaluative dimension of what refers to the extent to which a person feels good, happy, or satisfied (Mehrabian \& Russell, 1974).

\section{Willingness to Pay}

For items in the market, a person's WTP is directly disclosed through their purchasing decision. However, some categories of goods and services are not traded on the market, such as public goods and utility service attributes. The implied preference approach, such as a contingent valuation survey, is the main mechanism by which valuations for non-market goods can be disclosed.

Unlike the purchasing decisions observed, the preference approach is stated to only reveal behavioral intentions rather than actual behavior. The same preference technique is widely 


\section{International Journal of Business Management and Economic Review}

Vol. 3, No. 01; 2020

ISSN: 2581-4664

used in the valuation of utility attributes because there is no market mechanism in which consumers can express their preferences for improving utility services. In contrast, utility companies, as well as policymakers, depend on the preference survey set to obtain respondents evaluations of proposed changes in service levels.

Because the stated preference method is a hypothetical scenario, they face a number of problems. One of the main concerns is that proposed changes in service quality, as described in the survey, can be interpreted differently by respondents. Respondents formed an assessment of the PAPs that they stated based on their perceptions of the proposed changes. The PAPs stated by respondents can be distorted if their perceptions of the quality of services proposed and intended by the survey are different. By adapting the terms (Blomquist \& Whitehead, 1998), respondents who are willing to pay can be defined as the difference between their expenditures and the improvement in the quality of services provided, and expenditures for the quality of the status quo service.

Research Hypothesis

From the discussion, authors formulate the hypothesis as follow.

$\mathrm{H} 1$ : special price effects impulsive buying;

$\mathrm{H} 2$ : shopping pleasure effects impulsive buying;

$\mathrm{H} 3$ : willingness to pay effects impulsive buying;

$\mathrm{H} 4$ : special price effects on hedonic purchase;

H5 : shopping pleasure effects hedonic purchase, and;

H6 : willingness to pay effects the hedonic purchase.

\section{RESEARCH METHOD}

The object of this research is the Suzuya Department Store in Banda Aceh. The variables of the research are special prices, shopping pleasure, willingness to pay, consumer hedonic and unplanned purchases of Suzuya Dept. Store Banda Aceh.Population refers to the whole group of people, events, or other things that researchers want to investigate. The population group is a collection of all elements in the population where the sample is taken. So, the sample is a subgroup or part of the population. In this study the intended population is all customers (consumers) of the SuzuyaDepartemen Store Banda Aceh. The population in this study is infinite so sampling is a non probability sampling. In this study, it takes 150 people as a sample. The data is tested and analyzed using Structural Equation Model (SEM) as a statistical method, with AMOS software as a tool.

\section{DISCUSSION RESULT}

\section{Confirmatory Factor Analysis}

The latent variable of leadership in the confirmatory model consists of 5 indicators as the forming dimension. The results of data processing for confirmatory factor analysis for all constructs in this study are shown in Figure 1. 
Vol. 3, No. 01; 2020

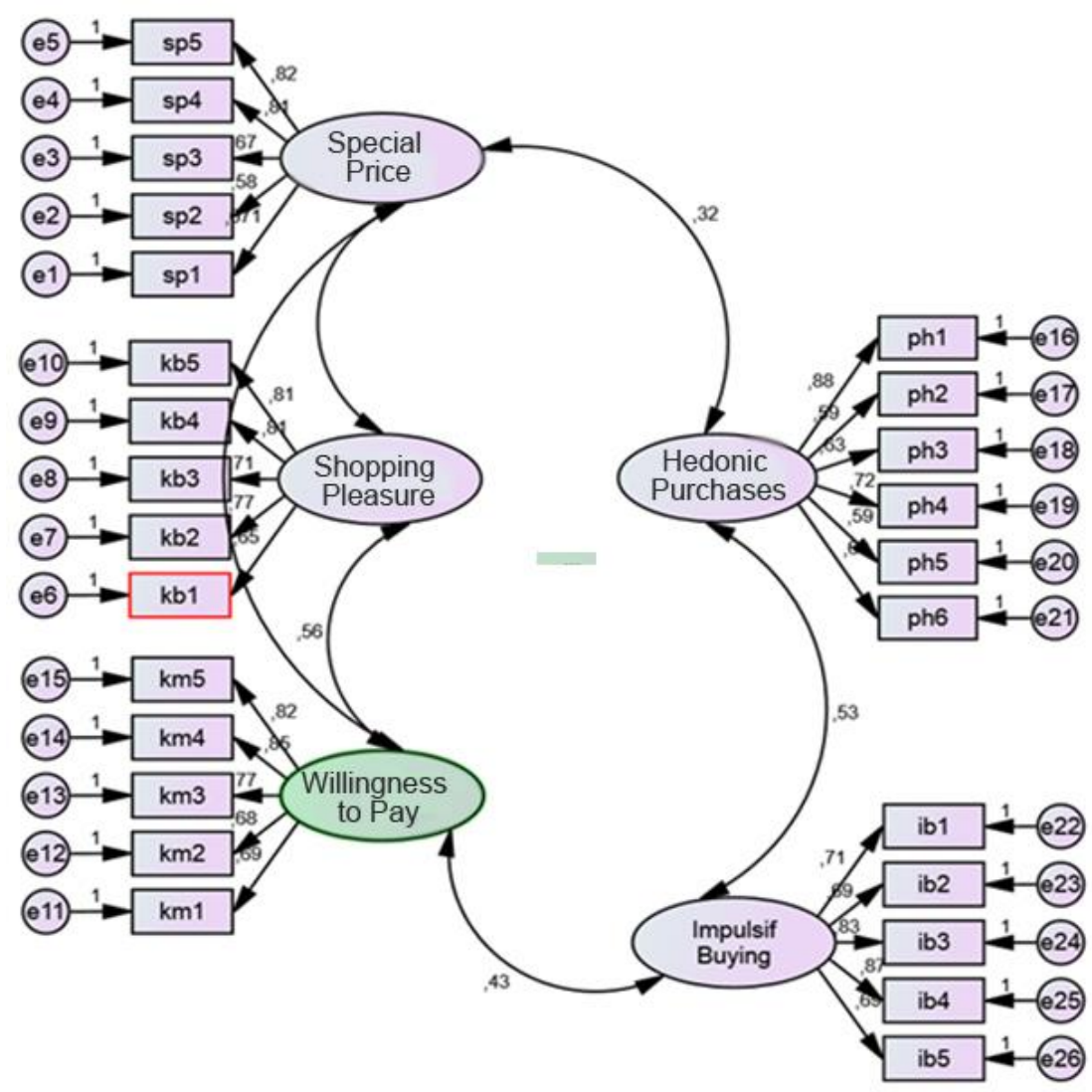

Figure 1. Confirmatory Factor Analysis

The analysis of the Structural Equation Model (SEM) in full model is carried out after an analysis of uni dimensionality level of the indicators forming latent variables is tested by confirmatory factor analysis. Analysis of data processing at the full stage of the SEM model is conducted by suitability tests and statistical tests. The results of data processing for full analysis of SEM modelis shown in Figure 2. 


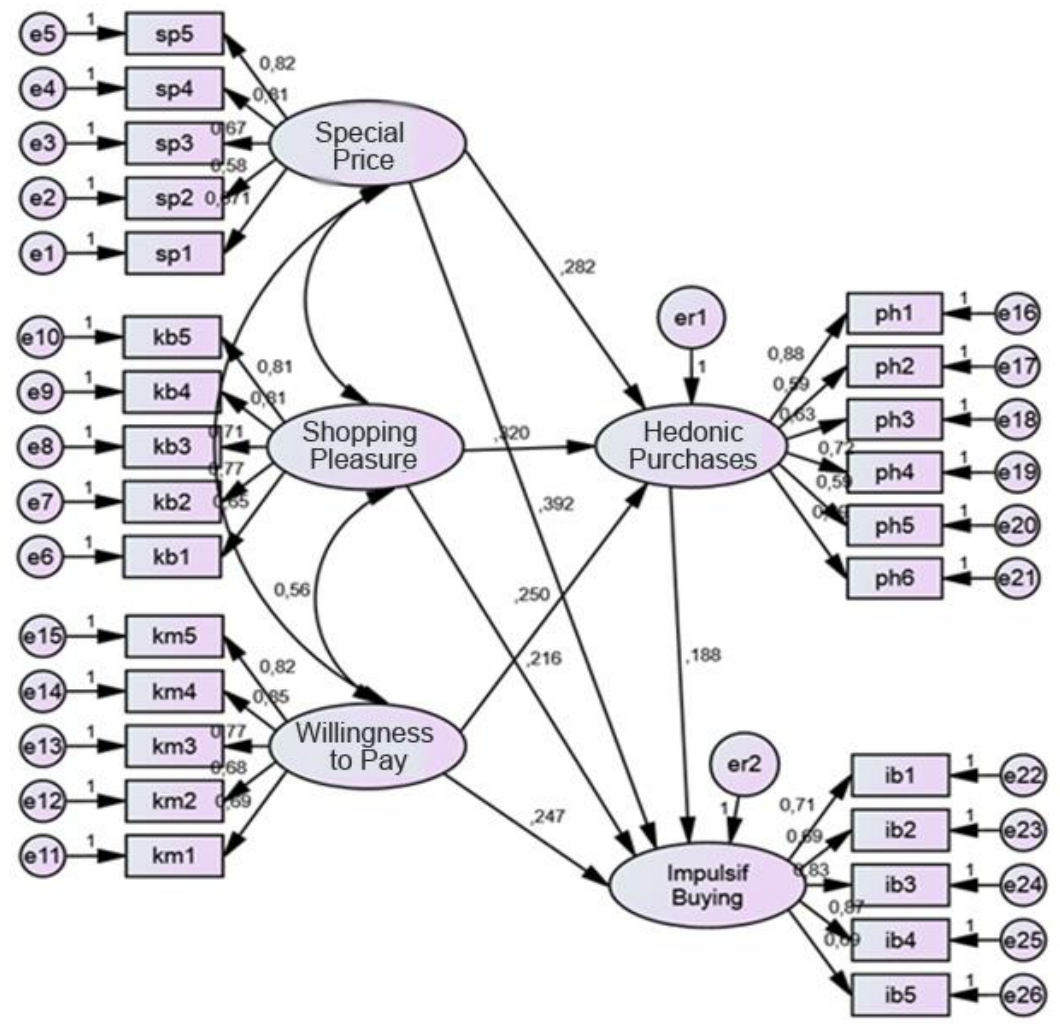

Figure 2. Result of Structural Equation Model (SEM)

\section{H1 Is Accepted : Effect Of Special Prices On Hedonic PurchaseAt Suzuya Department Store In Banda Aceh}

The effect of special price on hedonic purchase obtained a CR value of 6.079 with a significance level of 0.000. Thus it describes that the special price offered by Suzuya Department Store Banda Aceh affects the purchase of hedonic consumers. The magnitude of the effect of special prices on hedonic purchases is 0.282 or $28.2 \%$. This indicates that with the increasing frequency of special price at the Suzuya Department Store, Banda Aceh will have a positive and tangible influence on the purchase of hedonic at the Suzuya Department Store in Banda Aceh.

\section{The Effect Of Shopping Pleasure On Hedonic PurchaseAt Suzuya Department StoresIn Banda Aceh}

The effect of shopping pleasure on hedonic purchase obtained a CR value of 6.740 with a significance level of 0.0001 . Thus it explains that the pleasure of shopping done by consumers influences the purchase of hedonic at the Suzuya Department Store in Banda Aceh. The magnitude of the influence of shopping pleasure on hedonic purchase is 0.320 or $32.0 \%$. This indicates that the higher the level of pleasure consumers shop will further increase the purchase 
International Journal of Business Management and Economic Review

Vol. 3, No. 01; 2020

ISSN: 2581-4664

of hedonic.

H3 is accepted : The Effect Of Willingness To Pay For The Hedonic Purchase Of At Suzuya Department Stores In Banda Aceh

The effect of willingness to pay for hedonic purchases obtained a CR value of 6.274 with a significance level of 0.0001 . Thus it concludes that the willingness to pay in accordance with consumer needs has an influence on the purchase of hedonic at the Suzuya Department Store in Banda Aceh. The magnitude of the effect of willingness to pay for hedonic purchase is 0.250 or $25.0 \%$. This indicates that the more appropriate the willingness to pay consumers will have an impact on the purchase of hedonic.

\section{H4 is accepted : The Effect of Hedonic Purchase on Impulsive Buying at Suzuya Department Store Banda Aceh}

The effect of hedonic purchasing on impulsive buying obtained a CR value of 6.579 with a significance level of 0.0001 . Thus it figures that hedonic purchases will affect the impulsive buying of the Suzuya Department Store in Banda Aceh. The magnitude of the effect of the special price on impulsive buying is 0.188 or $18.8 \%$. This indicates that the higher the purchase of hedonic will directly influence the increase in impulsive buying of the Suzuya Department Store in Banda Aceh.

H5 is accepted : The Effect of Special Price on Impulsive Buying Suzuya Department Store Banda Aceh

The effect of special prices on impulsive buying obtained a CR value of 4.253 with a significance level of 0.0001 . Thus it describes that the special price has an effect on impulsive buying at the Suzuya Department Store in Banda Aceh. The magnitude of the influence of shopping pleasure on impulsive buying is 0.392 or $39.2 \%$. This indicates that the more frequently applied special prices will have an effect on increasing the impulsive buying of the Suzuya Department Store in Banda Aceh.

H6 Is Accepted : The EffectOf The Shopping Pleasure On Impulsive Buying At The Suzuya Department Store In Banda Aceh

The effect of pleasure shopping on impulsive buying obtained a CR value of 4.296 with a significance level of 0.0001 . Thus it explains that the pleasure of shopping for consumers at the Suzuya Department Store in Banda Aceh has an influence on increasing impulsive buying at the Suzuya Department Store in Banda Aceh. The magnitude of the influence of shopping pleasure on impulsive buying is 0.216 or $21.6 \%$.

H7 is accepted : Effect of Willingness to Pay Against Impulsive Buying at the Suzuya Department Store in Banda Aceh

The effect of willingness to pay against impulsive buying obtained a CR value of 3.634 


\section{International Journal of Business Management and Economic Review}

Vol. 3, No. 01; 2020

ISSN: 2581-4664

with a significance level of 0.0001 . Thus it can be concluded that the willingness to pay owned by consumers at the Suzuya Department Store in Banda Aceh has an influence on increasing impulsive buying at the Banda Aceh Suzuya Department Store, especially with regard to willingness to pay by consumers to influence impulsive buying. The magnitude of the influence of shopping pleasure on impulsive buying is 0.247 or $24.7 \%$.

\section{RESULT DISCUSSION}

The results of this study as a whole are consistent with previous research conducted by (Semuel, 2005) which states that the special prices applied by the Suzuya Department Store Banda Aceh have an influence on the level of purchase of hedonic. Then the results of this study are also consistent with the research conducted by (Satriawan, Hartoyo, \& Yuliati, 2015) saying that Utilitarian Motivation is when someone will shop and someone feels that they get the benefits of a product they want. This motivation is based on objective thinking. Thus utilitarian shopping motivation is a motivation where consumers do shopping activities because they really need or want to get the benefits of a product itself. There are two things that must be considered in utilitarian motivation, namely, quality of goods and service quality.

Then the willingness to pay made by consumers will have an influence on impulsive buying through hedonic purchases made by consumers. The results of this study are consistent with the research conducted by (Sumarwan, 2011) which states that consumer behavior is all activities, actions, and psychological processes that encourage these actions when buying, when buying, using, spending products and services or evaluation activities. The study of consumer behavior is a study of how an individual makes a decision to allocate available resources (time, money, effort, and energy). Willingness to pay is an attitude that is psychologically carried out by consumers to make payments for products that will be obtained, where the willingness to pay is one form of sacrifice from consumers to get the goods they want.

\section{CONCLUSIONS}

The results of the study also prove that : special price effects impulsive buying; shopping pleasure effects impulsive buying; willingness to pay effects impulsive buying; special prices have an effect on hedonic purchase; then shopping pleasure effects hedonic purchase; willingness to pay effects the purchase of consumer hedonic Suzuya Department Store Banda Aceh; and hedonic purchases effects the impulsive buying of consumers at the Suzuya Department Store in Banda Aceh. With the findings we can map the managerial implication to figures the condition. Hedonic and impulsive buying made by consumers at the Banda Aceh Suzuya Department Store should be considered by consumers, especially with regard to special price, the Suzuya Department Store should provide discounts for some favorite products, so consumers can still reach the desired product.Then the the management needs to find the marketing campaign to attract and increase the shopping pleasure, willingness to Pay, hedonic purchase and Impulsive Buying of the consumers that come to Banda Aceh Suzuya Department Store.

These all findings also have an implication to academic area. There will be as a reference for further research to be developed, as this research proves the causality theories and this is being a new premise/ update theories. The originality lies in the integration of the causality test from the previous researches, and also the use of SEM as a statistical approach. The 


\section{International Journal of Business Management and Economic Review}

Vol. 3, No. 01; 2020

ISSN: 2581-4664

limitation is in the number of variables that are only four, and with one object.

\section{REFERENCES}

Applebaum, W. (1951). Studying Customer Behavior in Retail Stores. Journal of Marketing, 16(2), 172-178. https://doi.org/https://doi.org/10.1177/002224295101600204

Arnold, M. J., \& Reynolds, K. E. (2003). Hedonic shopping motivations. Journal of Retailing, 79(2), 77-95.

Bellenger, D. N., Robertson, D. H., \& Hirschman, E. . (1978). Impulse buying varies by product. Journal of Advertising Research, 18, 15-18.

Blomquist, G. C., \& Whitehead, J. C. (1998). Resource quality information and validity of willingness to pay in contingent valuation. Resource and Energy Economics, 20(2), 179196.

Budisantoso, T., \& Mizerski, K. (2011). The Influence of Shopping Motivation, Optimum Stimulation Level, Perception of Store Atmosphere, and Satisfaction on Repatronage Intention. ECU Publications Pre. Department of Management, College of Business and Economics, University of Canterbury.

Burgess, S., Dickson, M., \& Macmillan, L. (2014). Selective Schooling Systems Increase Inequality. London.

Çakmak, A. Ç., \& Çakır, M. (2012). Analysis of Hedonic Consumption Behaviours of the Young People Aged 12-18: A Research in the City Center of Kocaeli. Tarih Kültür ve Sanat Araștırmaları Dergisi, 1(4), 545-565. https://doi.org/10.7596/taksad.v1i4

Činjarević, M., Tatic, K., \& Petric, S. (2011). See It, Like It, Buy It! Hedonic Shopping Motivations and Impulse Buying. Economic Review : Journal of Economics and Business, IX(1), 3-15.

Clover, V. T. (1950). Relative Importance of Impulse-Buying in Retail Stores. Journal of Marketing, 15(1), 66-70. https://doi.org/https://doi.org/10.1177/002224295001500110

Co, E. I. D. de N. and. (n.d.). Consumer Buying Habit Studies.

Cobb, C. J., \& Hoyer, W. D. (1986). Planned versus impulse purchase behavior. Journal of Retailing, 62(4), 384-409.

Dawson, S., \& Kim, M. (2009). External and internal trigger cues of impulse buying online. Direct Marketing An International Journal, 3(1), 20-34.

Dolan, R. J., \& Simon, H. (1996). Power Pricing: How Managing Price Transforms the Bottom Line. New York: The Free Press.

Donovan, R. J., Rossiter, J. R., Marcoolyn, G., \& Nesdale, A. (1994). Store atmosphere and purchasing behavior. Journal of Retailing, 70(3), 283-294.

Erkmen, T., \& Yuksel, C. A. (2008). Tuketicilerin Alisveris Davranis Bicimleri Ile Demografik ve Sosyo Kulturel Ozelliklerinin Incelenmesine Yonelik Bir Arastirma. Ege Academic Review, 8(2), 683-727.

Fazila, R. (2018). Mekanisme Pemeriksaan Laporan Realisasi Fisik Dan Keuangan Dana Otsus Per Triwulan Tahun 2016 Pada Biro Administrasi Pembangunan Setda Aceh. Syiah Kuala University.

Ginting, T. W., \& Nasri, M. (2018). Willingness To Pay Mahasiswa Untuk Berhenti Merokok. Jurnal Ilmiah Mahasiswa Ekonomi Pembangunan, 3(2), 223-232.

Hirschman, E. C., \& Holbrook, M. B. (1982). Hedonic Consumption: Emerging Concepts, 


\section{International Journal of Business Management and Economic Review}

Vol. 3, No. 01; 2020

ISSN: 2581-4664

Methods and Propositions. Journal of Marketing, 46(3), 92-101. https://doi.org/DOI: $10.2307 / 1251707$

Holbrook, M. B. (1986). The Role of Emotion in the Consumption Experience: Actions and Reactions in Consumer Behavior. Advances in Consumer Research, 13, 666.

Jackson, J., Currie, K., Graham, C., \& Robb, Y. (2011). The effectiveness of interventions to reduce undernutrition and promote eating in older adults with dementia: A systematic review. Systematic Reviews and Implementation Reports, 9(37), 1509-1550.

https://doi.org/doi: 10.11124/jbisrir-2011-119

Katona, G., \& Mueller, E. (n.d.). Consumer Expectations.

Kenny, B., \& Dyson, K. (2018). Marketing in Small Businesses (1 edition). London: Routledge.

Kollat, D. T., \& Willett, R. P. (1969). Is Impulse Purchasing Really a Useful Concept for Marketing Decisions? Journal of Marketing, 33(1), 79-83.

Kotler, P., \& Keller, K. L. (2018). Marketing Management, Global Edition (15th editi). Harlow, United Kingdom: Pearson.

Langrehr, F. W. (1991). Retail Shopping Mall Semiotics and Hedonic Consumption. Advances in Consumer Research, 8, 428433.

Mai, B., Menon, N., \& Sarkar, S. (2006). Online Privacy at a Premium. Proceedings of the 39th Hawaii International Conference on System Sciences (HICSS '06).

Mary Jo Bitner. (1992). Servicescapes: The Impact of Physical Surroundings On Customers and Employees. Journal Of Marketing, 56, 57-71. Retrieved from http://www.ida.liu.se/ steho87/und/htdd01/9208310667.pdf

Mehrabian, A., \& Russell, J. A. (1974). An approach to environmental psychology. Cambridge, MA, US: The MIT Press.

Mowen, J. C., \& Minor, M. (2002). Perilaku konsumen ( alih bahasa D. K. Yahya, Ed.). Jakarta: Erlangga.

Ozdemir, Y. (2007). The Role of Classroom Management Efficacy in Predicting Teacher Burnout. International Journal of Human and Social Sciences, 2(4), 7. Retrieved from http://www.waset.ac.nz/journals/ijhss/v2/v2-4-40.pdf

Rook, D. W. (1987). The Buying Impulse. Journal of Consumer Research, 14(2), 189-199.

Rook, D. W., \& Hoch, S. J. (1985). Share Consuming Impulses. NA - Advances in Consumer Research, 12.

Satriawan, S. B., Hartoyo, \& Yuliati, L. N. (2015). Hedonisme Konsumen Sebagai Variabel Mediator Antara Pemasaran Dan Pembelian Tidak Terencana. Jurnal Ilmu Keluarga Dan Konsumen, 8(1). https://doi.org/DOI: https://doi.org/10.24156/jikk.2015.8.1.59

Semuel, H. (2005). Respons Lingkungan Berbelanja Sebagai Stimulus Pembelian Tidak Terencana Pada Toko Serba Ada (Toserba) (Studi Kasus Carrefour Surabaya). Jurnal Manajemen Dan Kewirausahaan, 7(2).

https://doi.org/https://doi.org/10.9744/jmk.7.2.pp.\%20152-170

Setiadi, N. J. (2013). Perilaku Konsumen (Edisi Revi). Jakarta: Kencana.

Sumarwan, U. (2011). Perilaku Konsumen: Teori dan Penerapannya dalam Pemasaran (R. Sikumbang, Ed.). Jakarta: PT Ghalia Indonesia.

Syahputra, A., Yunus, M., \& Ibrahim, M. (2017). Pengaruh Gaya Hidup Hedonisme, Materialisme Dan Pendapatan Terhadap Shopping Lifesyle Serta Dampaknya Pada Pembelian Impulsif Online Produk Fashion Pada Masyarakat Kota Banda Aceh. Jurnal 
International Journal of Business Management and Economic Review

Vol. 3, No. 01; 2020

ISSN: 2581-4664

Manajemen Dan Inovasi, 8(3), 65-75.

Vohs, K., \& Faber, R. J. (2007). Spent Resources: Self-Regulatory Resource Availability Affects Impulse Buying. Journal of Consumer Research, 33(4), 537-547.

Weinberg, P., \& Gottwald, W. (1982). Impulsive consumer buying as a result of emotions.

Journal of Business Research, 10(1), 43-57. 